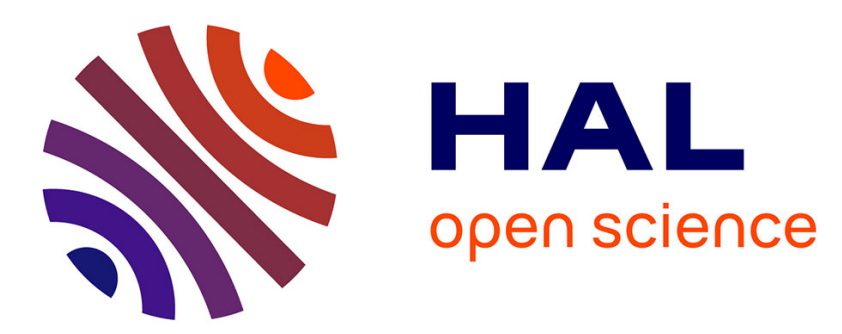

\title{
Equations of pressuremeter curve with an elastic strain-softening plastic model
}

Christophe Dano, Pierre-Yves Hicher

\section{To cite this version:}

Christophe Dano, Pierre-Yves Hicher. Equations of pressuremeter curve with an elastic strainsoftening plastic model. International Symposium on Numerical Models in Geomechanics, NUMOG VIII, 2002, Rome, Italy. hal-01008136

\section{HAL Id: hal-01008136 https://hal.science/hal-01008136}

Submitted on 13 Mar 2018

HAL is a multi-disciplinary open access archive for the deposit and dissemination of scientific research documents, whether they are published or not. The documents may come from teaching and research institutions in France or abroad, or from public or private research centers.
L'archive ouverte pluridisciplinaire HAL, est destinée au dépôt et à la diffusion de documents scientifiques de niveau recherche, publiés ou non, émanant des établissements d'enseignement et de recherche français ou étrangers, des laboratoires publics ou privés. 


\title{
Equations of pressuremeter curve with an elastic strain - softening plastic model
}

\author{
C. Dano \& P.Y. Hicher \\ Civil Engineering Laboratory of Nantes Saint-Nazaire, Ecole Centrale of Nantes, France
}

\begin{abstract}
We propose analytical expressions of the pressuremeter curve that generalise previous equations found in the literature. We consider a linear elastic plastic model with strain-softening, assuming a Mohr-Coulomb yield surface. The softening behaviour affects either the cohesion or the friction angle. Three parameters are required to describe the softening behaviour. We finally show the effect of each of these three parameters on the pressuremeter curve.
\end{abstract}

\section{INTRODUCTION}

The development of numerical methods has enabled to interpret the pressuremeter tests otherwise than through the conventional pressuremeter characteristics (limit pressure, pressuremeter modulus) (French Standard NF P 94-110, 1991; American Standard ASTM D 4719-87, 1994). Indeed, for a design purpose, the identification procedure of constitutive model parameters by inverse analysis of these in situ tests has known a great progress (Shao et al. 1991; Kasdi 1994; Zentar et al. 2001).

This mathematical approach consists in optimising the values of the model by comparison between experimental and computed results. Depending on the degree of refinement of the constitutive model, computations can be performed either numerically using a finite element code or analytically. In the last case, the linear elastic perfectly plastic model with a non standard MohrCoulomb failure criterion (Fig. 1) has been usually considered in the literature (Hughes et al. 1977; Monnet \& Khlif 1994; Monnet \& Chemaa 1995; Bornarel 1999).

However, by means of finite element computations, Prevost \& Hoëg (1975), Carter \& Yeung (1985) have shown the effect of a strain hardening or a strain softening behaviour on the stress distribution around the pressure probe and, as a consequence, on the pressuremeter curve itself. We therefore develop analytical expressions of the pressuremeter curve considering a gradual loss of resistance from the peak strength to the residual strength (Fig. 1).

\section{THE CONSTITUTIVE MODEL}

\subsection{Elasticity and yield functions}

The model adopted is a linear and isotropic elastic plastic model with a post-failure strain softening. The elastic part typically obeys the Hooke's law:

$\underline{\underline{\sigma}}=\lambda \times \operatorname{Tr}(\underline{\underline{\varepsilon}}) \bullet \underline{\underline{I}}+2 \mu \times \underset{=}{\varepsilon}$

where $\sigma=$ stress tensor, $\varepsilon=$ strain tensor, $\lambda$ and $\mu=$ Lamé's constants, I = identity matrix. In this paper, we also use the Young's modulus $\mathrm{E}$ and the Poisson's ratio $v$ instead of the Lamé's constants. Stresses and strains are negative in compression and positive in extension.

We also assume Mohr-Coulomb yield functions:

$\left.\mathrm{F}_{1} \underline{\underline{\sigma}}, \mathrm{k}_{1}\right)=\left(\sigma_{3}-\sigma_{1}\right)+\sin \varphi \times\left(\sigma_{3}+\sigma_{1}\right)$

$-2 \mathrm{C} \times \mathrm{k}_{1}\left(\varepsilon_{\mathrm{d}}^{\mathrm{p}}\right) \times \cos \varphi$

$\mathrm{F}_{2}\left(\underline{\underline{\sigma}}, \mathrm{k}_{2}\right)=\left(\sigma_{3}-\sigma_{1}\right)+\mathrm{k}_{2}\left(\varepsilon_{\mathrm{d}}^{\mathrm{p}}\right) \times \sin \varphi \times\left(\sigma_{3}+\sigma_{1}\right)$

where $\mathrm{C}=$ cohesion, $\varphi=$ friction angle. $\sigma_{1}$ and $\sigma_{3}$ are respectively the major and the minor principal stresses. $\mathrm{k}_{1}$ and $\mathrm{k}_{2}$ are equal to unity at the peak strength.

The yield function (Eq. 2a) is considered in the case of cohesive and frictional materials for which the cohesion is gradually reduced (C-softening model). The friction angle is kept constant in the plastic domain. 


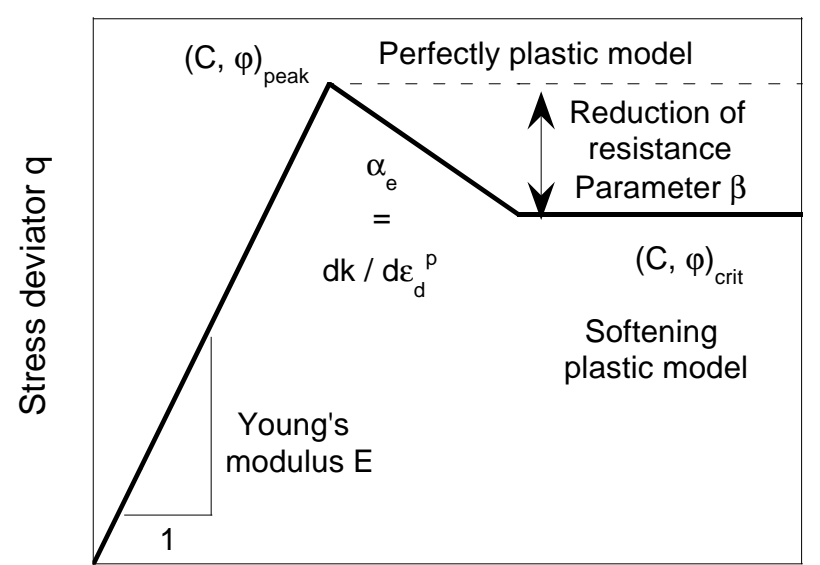

Deviatoric strain $\varepsilon_{d}$

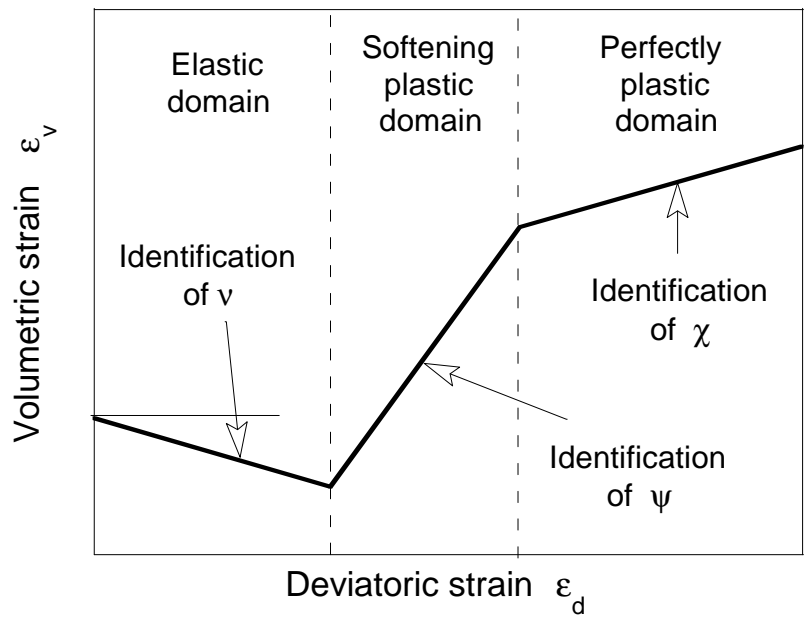

Figure 1. The constitutive model.

The yield function (Eq. 2b) applies to purely frictional materials for which the friction angle gradually decreases $(\varphi$-softening model).

At the residual strength, in the perfect plasticity domain, the functions $\mathrm{k}_{1}$ and $\mathrm{k}_{2}$ are equal to the additional parameter of the model $\beta$.

Before clarifying the functions $\mathrm{k}_{1}$ and $\mathrm{k}_{2}$, let us precise that the plastic strains follow a non-standard flow rule:

$\mathrm{d} \varepsilon^{\mathrm{p}}=\mathrm{d} \xi \times \frac{\partial \mathrm{G}(\underline{\underline{\sigma}})}{\partial \sigma}$

where $\mathrm{G}=$ plastic potential is written in the following way:

$\mathrm{G}(\underline{\underline{\sigma}})=\left(\sigma_{3}-\sigma_{1}\right)+\chi \times \sin \psi \times\left(\sigma_{3}+\sigma_{1}\right)$

where $\mathrm{d} \xi=$ plastic multiplier, $\psi=$ dilatancy angle identified at the maximal rate of dilating volumetric strains and $\chi=$ reduction ratio $(\chi<1)$ of the dilatancy in the perfect plasticity domain.

We also consider the following notations:

$\mathrm{R}_{\mathrm{t}}=\frac{2 \mathrm{C} \times \cos \varphi}{1+\sin \varphi}$

$$
\begin{aligned}
& \mathrm{k}_{\mathrm{p}}=\frac{1-\sin \varphi}{1+\sin \varphi} \\
& \mathrm{n}_{\chi}=\frac{1-\chi \sin \psi}{1+\chi \sin \psi}
\end{aligned}
$$

\subsection{The strain softening behaviour}

As previously done by Yuritzinn (1981), we assume that the functions $\mathrm{k}_{1}$ and $\mathrm{k}_{2}$ linearly decrease with the deviatoric plastic strain $\varepsilon_{\mathrm{d}}{ }^{\mathrm{p}}$ such as:

$\mathrm{k}_{\mathrm{i}}\left(\varepsilon_{\mathrm{d}}^{\mathrm{p}}\right)=1+\alpha_{\mathrm{e}} \varepsilon_{\mathrm{d}}^{\mathrm{p}}=1+\alpha_{\mathrm{e}}\left(\varepsilon_{1}^{\mathrm{p}}-\varepsilon_{3}^{\mathrm{p}}\right) \quad \mathrm{i}=1,2$

where $\alpha_{e}$ represents the softening rate. For low values of the parameter $\alpha_{e}$, the decrease of resistance is quite slow and the softening domain is quite wide whereas high values of $\alpha_{e}$ account for brittle behaviour.

The constitutive model is characterised by eight parameters since three dimensionless parameters $\left(\alpha_{e}\right.$, $\beta, \chi)$ are added to the five parameters $(\lambda, \mu, \varphi, C, \psi)$ of the linear elastic perfectly plastic Mohr-Coulomb model.

\section{EQUATIONS OF THE PRESSUREMETER CURVES}

The determination of the pressuremeter curve, that is to say the relation that links the pressure $p$ into the probe to the deformation at the cavity wall $u(a) / a$ (u(a) is the displacement of the wall, a the initial radius of the borehole), is a typical mechanical problem of cavity expansion into an infinite medium (Hughes et al. 1977; Yu \& Houlsby 1991).

\subsection{Additional assumptions}

In order to obtain an analytical expression, the following assumptions have to be made:

- hypothesis of small strains: elastic strain $\varepsilon^{\mathrm{e}}$ and plastic strain $\varepsilon^{\mathrm{p}}$ are related to the total strain $\varepsilon$ by the partition rule:

$\varepsilon=\varepsilon^{\mathrm{e}}+\varepsilon^{\mathrm{p}}$

- isotropic initial stress state: in other words, the coefficient of earth pressure at rest $\mathrm{K}_{0}$ is equal to 1 ;

- homogeneous and isotropic medium, isotropic strain softening;

- axisymmetrical problem with a cylindrical coordinates system $(r, \theta, z)$ where the subscript $r$ means the radial direction, $\theta$ the circumferential one and $\mathrm{z}$ the vertical one; 
- the assumption of plane strain conditions is practically justified by the use of guard cells on both sides of the probe;

- the vertical stress remains the intermediate principal stress;

- in the plastic domain following the peak strength, the elastic strain remains constant and equal to its value at peak.

\subsection{General equations}

For sake of simplicity, we just precise the general equations required to solve the mechanical problem. More details concerning the mathematical developments can be found in (Dano 2001). The problem is governed by:

- the equilibrium equations in the horizontal plane:

$\frac{\mathrm{d} \sigma_{\mathrm{r}}(\mathrm{r})}{\mathrm{dr}}-\frac{\sigma_{\theta}(\mathrm{r})-\sigma_{\mathrm{r}}(\mathrm{r})}{\mathrm{r}}=0$

- the compatibility rules that link the displacements $\mathrm{u}$ to the strains:

$\varepsilon_{\mathrm{r}}(\mathrm{r})=\frac{\mathrm{du}(\mathrm{r})}{\mathrm{dr}}$

$\varepsilon_{\theta}(r)=\frac{u(r)}{r}$

- the initial and boundary conditions: at the cavity wall, the radial stress $\sigma_{\mathrm{r}}$ is equal to the pressure $\mathrm{p}$ into the probe, apart from the minus sign:

$\sigma_{\mathrm{r}}(\mathrm{r}=\mathrm{a})=-\mathrm{p} \quad \mathrm{p}>0$

whereas, to infinity, we assume that the soil is undisturbed:

$\sigma_{\mathrm{r}}(\mathrm{r} \rightarrow \infty)=-\mathrm{p}_{0} \quad \mathrm{p}_{0}>0$

where $\mathrm{p}_{0}=$ initial earth pressure at rest;

- the constitutive model;

- the continuity of the radial stress at the interfaces respectively between the elastic domain and the softening plastic domain (for $r=c$ ) and between the softening plastic domain and the perfect plasticity domain (for $r=b$ ) (Fig. 2).

\subsection{Mathematical developments}

Distinct expressions of the pressuremeter curve have to be considered depending on the value of the pressure $p$ into the probe. Indeed, for small values of the pressure, clearly for $\mathrm{p}<\mathrm{p}_{\mathrm{pl}}$, the soil behaves elastically until the yield shear strength is reached. Then, for a value of the pressure $\mathrm{p}$ greater than $\mathrm{p}_{\mathrm{pl}}$, a softening plastic zone develops concentrically to the borehole. Finally, for pressures greater than $\mathrm{p}_{\mathrm{pa}}$, the perfectly plastic zone develops also concentrically.

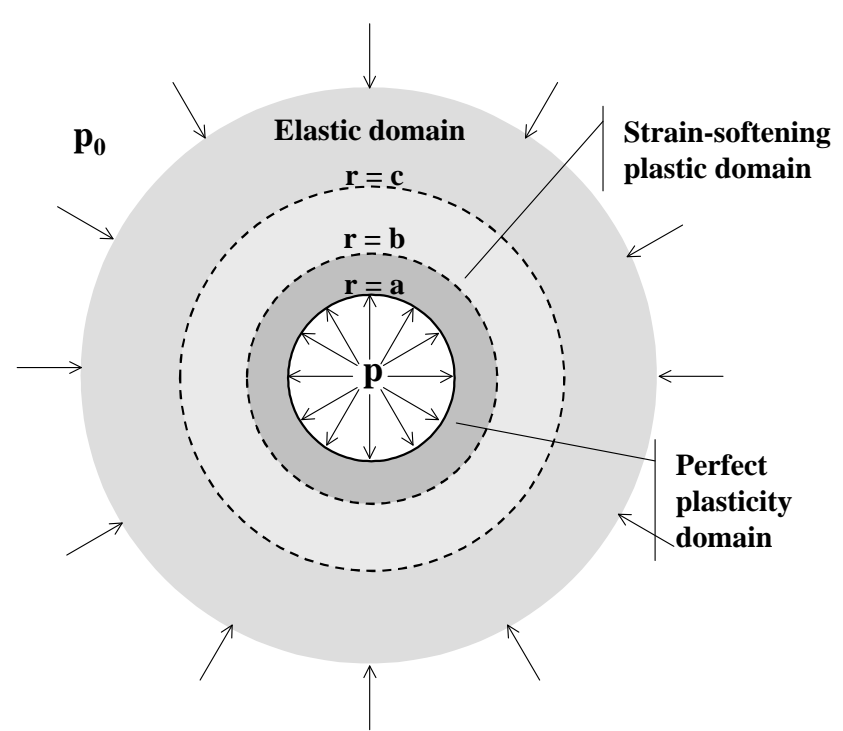

Figure 2. Successive behaviours around the cavity.

In all cases, the combination of equations (1), (2), (3), (6), (7), (8) and (9) leads to a first order differential equation with a second member such as:

$\frac{\mathrm{d} \sigma_{\mathrm{r}}(\mathrm{r})}{\mathrm{dr}}+\sigma_{\mathrm{r}}(\mathrm{r}) \times \mathrm{g}(\mathrm{r})=\mathrm{h}(\mathrm{r})$

where the functions $g(r)$ and $h(r)$ depend on the function $\mathrm{k}_{\mathrm{i}}$. The solution can be formally written:

$\sigma_{r}(r)=e^{-G(r)} \times\left[T^{\prime}+\int_{r} h(r) \times e^{G(r)} d r\right]$

where $\mathrm{G}=$ primitive of the function $\mathrm{g}$ and $\mathrm{T}^{\prime}=$ constant determined by the use of the continuity conditions.

We have also to express the variation of the functions $\mathrm{k}_{1}$ and $\mathrm{k}_{2}$ with the radius $\mathrm{r}$ from the center of the cavity. It is quite straightforward to find that:

$$
\begin{aligned}
& \mathrm{k}_{\mathrm{i}}(\mathrm{r})=\left(1+2 \alpha_{\mathrm{e}} \frac{\mathrm{k}_{3}}{\mathrm{c}^{2}}\right)-2 \alpha_{\mathrm{e}} \frac{\mathrm{k}_{3}}{\mathrm{c}^{2}}\left(\frac{\mathrm{c}}{\mathrm{r}}\right)^{1+\mathrm{n}_{1}}= \\
& \mathrm{k}_{10}+\mathrm{k}_{11}\left(\frac{\mathrm{c}}{\mathrm{r}}\right)^{1+\mathrm{n}_{1}}
\end{aligned}
$$

with

$\frac{\mathrm{k}_{3}}{\mathrm{c}^{2}}=\frac{\mathrm{C} \times \cos \varphi+\mathrm{p}_{0} \times \sin \varphi}{2 \mu}$

In order to determine the plastic radii $b$ and $c$ and the pressures $\mathrm{p}_{\mathrm{pl}}$ and $\mathrm{p}_{\mathrm{pa}}$, we finally assume that the ratio between the radii $c$ and $b$ is set to a constant value $R_{\text {lim }}$ when the perfectly plastic state is reached. This implies that: 
$\mathrm{R}_{\lim }=\left(\frac{\mathrm{c}}{\mathrm{b}}\right)_{\lim }=\left[1+\frac{1-\beta}{2 \alpha_{\mathrm{e}} \frac{\mathrm{k}_{3}}{\mathrm{c}^{2}}}\right]^{\frac{1}{1+\mathrm{n}_{1}}}$

The evolution of $R_{\lim }$ as a function of $\alpha_{e}$ and $\beta$ is presented in Figure 3. Then, we show that:

$\mathrm{p}_{\mathrm{pl}}=\mathrm{C} \times \cos \varphi+\mathrm{p}_{0} \times(1+\sin \varphi)$

and

$\mathrm{p}_{\mathrm{pa}}=\mathrm{p}_{\mathrm{pl}} \times \mathrm{M}^{\frac{2}{\left(1+\mathrm{n}_{1}\right)\left(1+\mathrm{k}_{10} \sin \varphi\right)}} \times \mathrm{R}_{\lim }^{\frac{2 \mathrm{k}_{10} \sin \varphi}{1+\mathrm{k}_{10} \sin \varphi}}$

with

$M=\left[\frac{1+\mathrm{k}_{10} \sin \varphi+\mathrm{k}_{11} \sin \varphi \mathrm{R}_{\lim }^{1+\mathrm{n}_{1}}}{1+\sin \varphi}\right]$

\subsection{Equations of the pressuremeter curve}

\subsubsection{Elastic domain}

If the pressure $\mathrm{p}$ into the probe is less than $\mathrm{p}_{\mathrm{pl}}$, then the soil behaves completely elastically. The equation of the pressuremeter curve is typically:

$\frac{\mathrm{u}(\mathrm{a})}{\mathrm{a}}=\frac{\mathrm{p}-\mathrm{p}_{0}}{2 \mu}$

This equation becomes suitable for $r \geq c$.

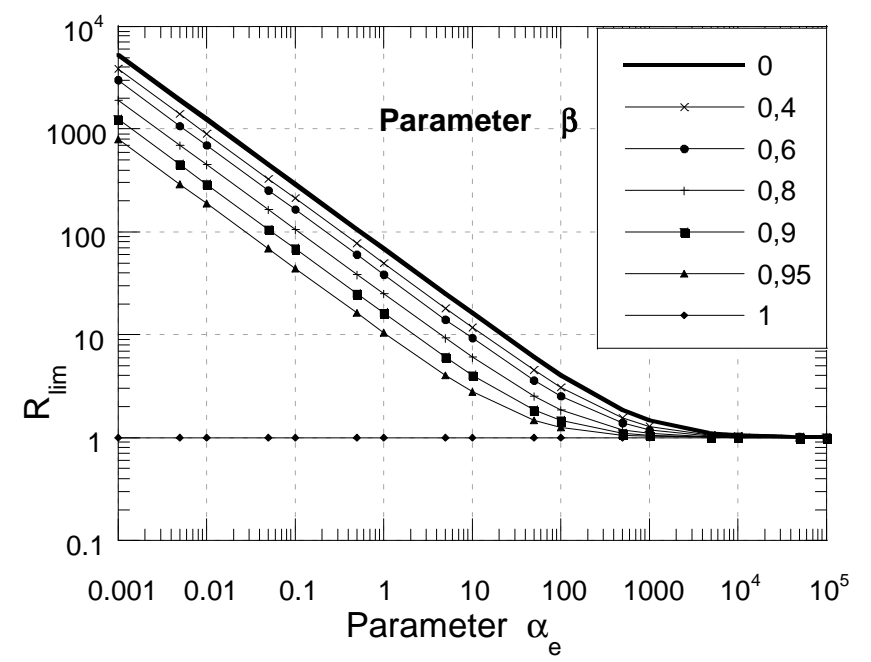

Figure 3. Evolution of the extent $\mathrm{R}_{\text {lim }}$ of the softening zone.

\subsubsection{Softening plastic domain}

If $\mathrm{p}$ is greater than $\mathrm{p}_{\mathrm{pl}}$ but less than $\mathrm{p}_{\mathrm{pa}}$, then a softening plastic zone develops. For $\mathrm{a} \leq \mathrm{r} \leq \mathrm{c}$, the deformation at the cavity wall is given by:

$\frac{\mathrm{u}(\mathrm{a})}{\mathrm{a}}=\frac{\mathrm{n}_{1}-1}{\mathrm{n}_{1}+1} \frac{\mathrm{k}_{3}}{\mathrm{c}^{2}}+\frac{2}{1+\mathrm{n}_{1}} \frac{\mathrm{k}_{3}}{\mathrm{c}^{2}}\left(\frac{\mathrm{c}}{\mathrm{a}}\right)^{1+\mathrm{n}_{1}}$
The ratio of the radii $\mathrm{c}$ and $\mathrm{a}$ in (Eq. 17) is identified by optimization of the subsequent polynomial functions deduced from the equilibrium equations (Eq. 7).

For the C-softening model, the polynomial function is:

$$
-\frac{\mathrm{R}_{\mathrm{t}} \mathrm{k}_{10}}{1-\mathrm{k}_{\mathrm{p}}}-\mathrm{N}_{1} \times\left(\frac{\mathrm{c}}{\mathrm{a}}\right)^{1-\mathrm{k}_{\mathrm{p}}}+\frac{\mathrm{R}_{\mathrm{t}} \mathrm{k}_{11}}{\mathrm{n}_{1}+\mathrm{k}_{\mathrm{p}}}\left(\frac{\mathrm{c}}{\mathrm{a}}\right)^{1+\mathrm{n}_{1}}=\mathrm{p}
$$

with

$$
\mathrm{N}_{1}=-\mathrm{p}_{0}-2 \mu \times \frac{\mathrm{k}_{3}}{\mathrm{c}^{2}}-\frac{\mathrm{R}_{\mathrm{t}} \mathrm{k}_{10}}{1-\mathrm{k}_{\mathrm{p}}}+\frac{\mathrm{R}_{\mathrm{t}} \mathrm{k}_{11}}{\mathrm{n}_{1}+\mathrm{k}_{\mathrm{p}}}
$$

For the $\varphi$-softening model, the polynomial function is:

$\mathrm{p}_{\mathrm{pl}}\left[\frac{1+\mathrm{k}_{10} \sin \varphi+\mathrm{k}_{11} \sin \varphi\left(\frac{\mathrm{c}}{\mathrm{a}}\right)^{1+\mathrm{n}_{1}}}{1+\sin \varphi}\right]^{\mathrm{N}_{2}}\left[\frac{\mathrm{c}}{\mathrm{a}}\right]^{\mathrm{N}_{3}}=\mathrm{p}$

with

$$
\begin{aligned}
& \mathrm{N}_{2}=\frac{2}{\left(1+\mathrm{n}_{1}\right)\left(1+\mathrm{k}_{10} \sin \varphi\right)} \\
& \mathrm{N}_{3}=\frac{2 \mathrm{k}_{10} \sin \varphi}{\left(1+\mathrm{k}_{10} \sin \varphi\right)}
\end{aligned}
$$

\subsubsection{Perfect plasticity domain}

Finally, if $\mathrm{p}$ is greater than $\mathrm{p}_{\mathrm{pa}}$, then a perfectly plastic zone develops. For $\mathrm{a} \leq \mathrm{r} \leq \mathrm{b}$, the deformation at the cavity wall is given by:

$$
\frac{\mathrm{u}(\mathrm{a})}{\mathrm{a}}=\varepsilon_{\theta}(\mathrm{b})\left[\frac{\mathrm{b}}{\mathrm{a}}\right]^{1+\mathrm{n}_{\chi}}+\frac{\mathrm{k}_{1}+\left(\mathrm{n}_{\chi}-1\right) \frac{\mathrm{k}_{3}}{\mathrm{c}^{2}}}{1+\mathrm{n}_{\chi}}\left[1-\left(\frac{\mathrm{b}}{\mathrm{a}}\right)^{1+\mathrm{n}_{\chi}}\right]
$$

with

$$
\begin{aligned}
& \varepsilon_{\theta}(\mathrm{b})=\frac{\mathrm{n}_{1}-1}{\mathrm{n}_{1}+1} \frac{\mathrm{k}_{3}}{\mathrm{c}^{2}}+\frac{2}{1+\mathrm{n}_{1}} \frac{\mathrm{k}_{3}}{\mathrm{c}^{2}}\left(\frac{\mathrm{c}}{\mathrm{b}}\right)_{\lim }^{1+\mathrm{n}_{1}} \\
& \mathrm{k}_{1}=\left(\mathrm{n}_{1}-\mathrm{n}_{\chi}\right) \times\left(\frac{\mathrm{k}_{3}}{\mathrm{c}^{2}}-\varepsilon_{\theta}(\mathrm{b})\right)
\end{aligned}
$$

For the C-softening model, the ratio (b/a) can be explicitly determined from the following equation:

$$
\begin{aligned}
& -\frac{\mathrm{R}_{\mathrm{t}} \mathrm{k}_{10}}{1-\mathrm{k}_{\mathrm{p}}}-\mathrm{N}_{1} \times\left(\frac{\mathrm{c}}{\mathrm{b}}\right)_{\lim }^{1-\mathrm{k}_{\mathrm{p}}}+\frac{\mathrm{R}_{\mathrm{t}} \mathrm{k}_{11}}{\mathrm{n}_{1}+\mathrm{k}_{\mathrm{p}}}\left(\frac{\mathrm{c}}{\mathrm{b}}\right)_{\lim }^{1+\mathrm{n}_{1}} \\
& =\left(\mathrm{p}+\frac{\beta \mathrm{R}_{\mathrm{t}}}{1-\mathrm{k}_{\mathrm{p}}}\right)\left(\frac{\mathrm{b}}{\mathrm{a}}\right)^{\mathrm{k}_{\mathrm{p}}-1}+\frac{\beta \mathrm{R}_{\mathrm{t}}}{1-\mathrm{k}_{\mathrm{p}}}
\end{aligned}
$$


IF

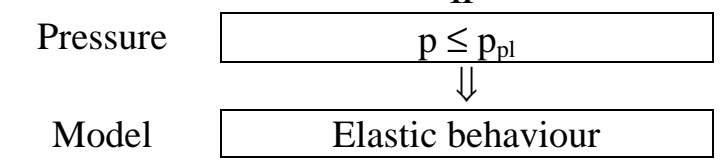

Ratio of radii

$\mathrm{u}(\mathrm{a}) / \mathrm{a}$
$\Downarrow$

Equation (16)
IF

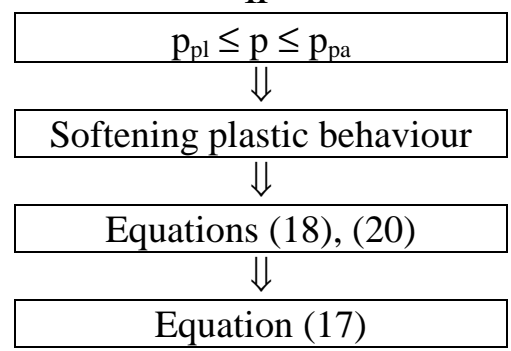

IF

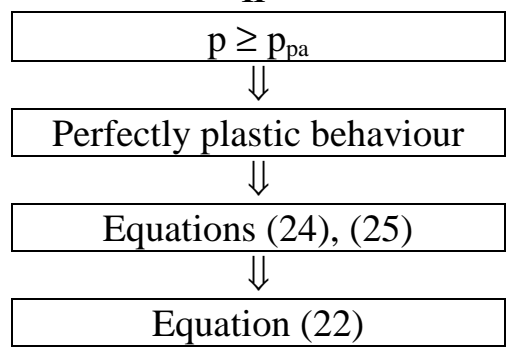

Figure 4. Procedure for the calculations of the pressuremeter curves.

since the ratio $(c / b)$ is definitively set to $R_{\text {lim. }}$.

For the $\varphi$-softening model, the ratio (b/a) is likewise given as

$$
\begin{aligned}
\text { follows: } & {\left[\frac{1+\mathrm{k}_{10} \sin \varphi+\mathrm{k}_{11} \sin \varphi\left(\frac{\mathrm{c}}{\mathrm{b}}\right)_{\lim }^{1+\mathrm{n}_{1}}}{1+\sin \varphi}\right]\left[\frac{\mathrm{c}}{\mathrm{b}}\right]_{\mathrm{lim}}^{\mathrm{N}_{3}} } \\
= & \mathrm{p}\left(\frac{\mathrm{a}}{\mathrm{b}}\right)^{\frac{2 \beta \sin \varphi}{1+\beta \sin \varphi}}
\end{aligned}
$$

\subsubsection{Synthesis}

Schematically, the pressuremeter curve is obtained as indicated in Figure 4. The problem is thus completely determined. The previous expressions have been confronted with well-known expressions of the pressuremeter curve presented in the literature, using an elastic perfectly plastic model (Hughes et al. 1977; Monnet \& Khlif 1994; Monnet $\&$ Chemaa 1995). For suitable values of the parameters $\alpha_{e}, \beta$ and $\chi$, our expressions fit exactly these more classical expressions.

Distribution of stresses around the cavity and corresponding strains can also be analytically calculated. Clear effect of the softening behaviour on stresses and strains was highlighted (Dano 2001).

\section{SENSITIVITY STUDY}

The constitutive model described in this paper involves eight parameters. The effect of the five first ones $(\lambda, \mu, \mathrm{C}, \varphi, \psi)$ is relatively well known (Kasdi 1994; Shahrour et al. 1995). Therefore we just present the influence of the three parameters describing the softening part $\left(\alpha_{e}, \beta, \chi\right)$ for the set of parameters indicated in Table 1. Results are shown only in the case of the $\mathrm{C}$-softening model.

Figures 5, 6, 7 successively illustrate the effect of $\alpha_{e}, \beta, \chi$ on the pressuremeter curve. As previously mentioned by (Carter \& Yeung 1985), these figures prove the relative importance of the post-failure strain softening on the shape of the pressuremeter curve. It depends on the volumetric behaviour (Fig. 7 ), not only in the softening plastic zone, but also in the perfectly plastic state through the parameter $\chi$.

The effects of the parameters $\alpha_{\mathrm{e}}$ and $\beta$ are also clearly established (Figs. 5, 6). Nevertheless, we have to put forward the difficulty to experimentally identify their values. In order to ensure the reliability of the constitutive model, further experimental work has to be carried out in order to justify the intrinsic (or not) nature of the softening behaviour. If its intrinsic feature is regularly questioned by strain localization or fracturation phenomena observed in axisymmetrical triaxial tests, the problem is more complex for pressuremeter-like stress paths.

Table 1. Set of parameters for the sensitivity study.

\begin{tabular}{llllll}
\hline $\mathrm{E}$ & \multirow{2}{*}{$v$} & $\mathrm{C}$ & $\varphi$ & $\psi$ & $\mathrm{p}_{0}$ \\
\cline { 3 - 6 } $\mathrm{MPa}$ & & $\mathrm{kPa}$ & degrees & degrees & $\mathrm{kPa}$ \\
\hline 500 & 0.25 & 150 & 39 & 15 & 200 \\
\hline$\alpha_{\mathrm{e}}$ & & & \\
$\chi$ & & From 0.1 To 1000 & \\
$\chi$ & & From 0 To 0.95 & \\
\hline
\end{tabular}

\section{CONCLUSIONS}

We developed analytical expressions of the pressuremeter curve assuming a linear elastic plastic model with a post-failure strain softening. The softening part whose effect is rather prevailing for high strains at the cavity wall was modeled using three additional parameters : the rate of degradation of the yield shear strength parameters (cohesion or friction angle), the value of the final degradation and the dilatation rate in the perfectly plastic state. These equations extend previous expressions of the pressuremeter curves found in the literature. Practical interests of these developments are to show the significant effect of the softening behaviour on the pressuremeter curve and to propose analytical formulations that can be easily implemented in a commercial software for parameter identification purposes. 


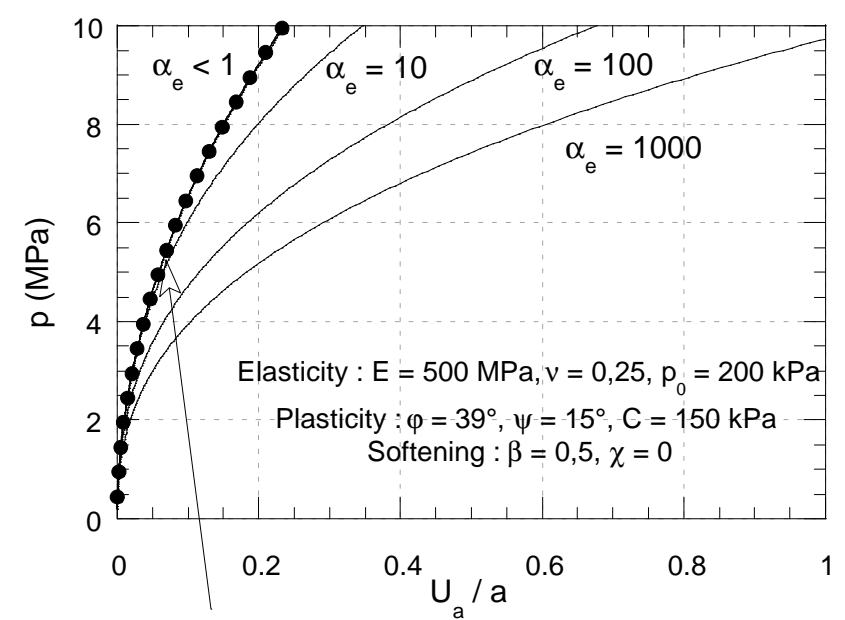

Points : Pressuremeter curve obtained with the linear elastic perfectly plastic model without strain-softening

Figure 5. Effect of the parameter $\alpha_{\mathrm{e}}$ on the pressuremeter curve.

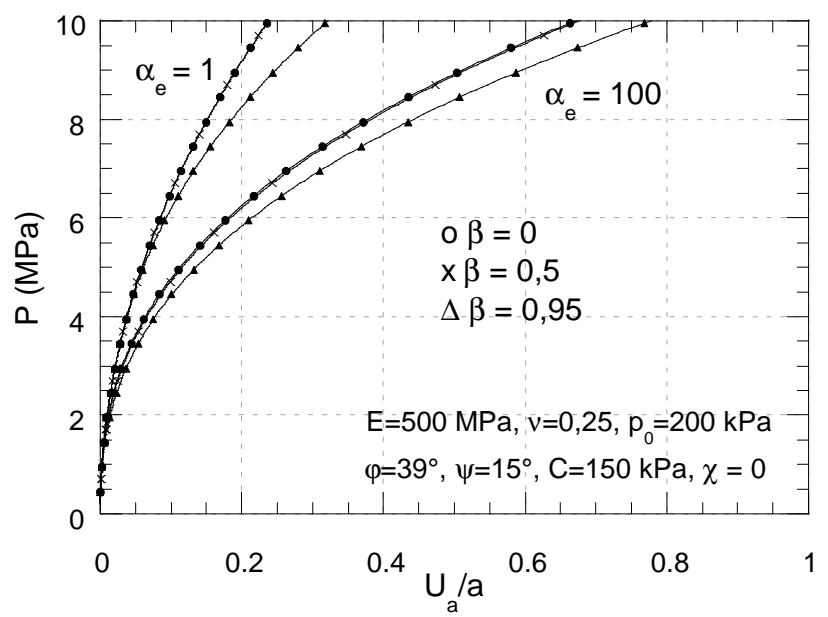

Figure 6. Effect of the parameter $\beta$ on the pressuremeter curve.

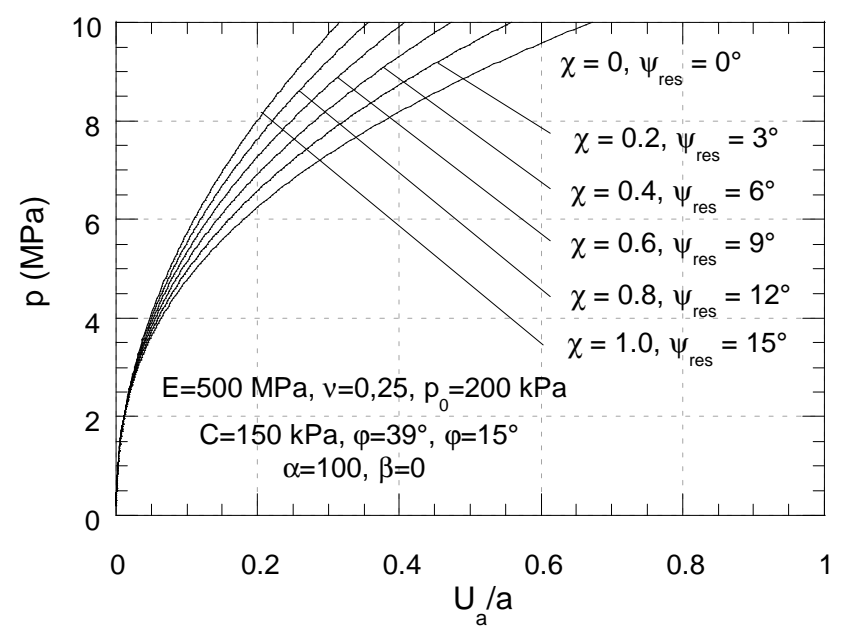

Figure 7. Effect of the parameter $\chi$ on the pressuremeter curve.
Borsetto, M. \& Ribacchi, R. 1979. Influence of the strainsoftening behaviour of rock masses on the stability of a tunnel. $3^{\text {rd }}$ International Conference on Numerical Methods in Geomechanics, Aachen: 611-620.

Cambou, B. \& Bahar, R. 1993. Utilisation de l'essai pressiométrique pour l'identification de paramètres intrinsèques du comportement d'un sol. Revue Française de Géotechnique 63: 39-50.

Carter, J.P. \& Yeung, S.K. 1985. Analysis of cylindrical cavity expansion in a strain weakening material. Computers and Geotechnics 1: 161-180.

Dano, C. 2001. Comportement mécanique des sols injectés. PhD. Thesis, Ecole Centrale de Nantes.

Hughes, J.M.O, Wroth, C.P. \& Windle, D. 1977. Pressuremeter tests in sands. Geotechnique 27(4): 455-477.

Kasdi, A. 1994. Détermination des paramètres des modèles élasto-plastiques à partir de l'essai pressiométrique. $P h D$. Thesis, Université des Sciences et Technologies de Lille.

Monnet, J. \& Khlif, J. 1994. Etude théorique et expérimentale de l'équilibre élasto-plastique d'un sol pulvérulent autour du pressiomètre. Revue Française de Géotechnique 67: 312.

Monnet, J. \& Chemaa, T. 1995. Etude théorique et expérimentale de l'équilibre élasto-plastique d'un sol cohérent autour du pressiomètre. Revue Française de Géotechnique 73: 15-26.

Prévost, J-H. \& Hoëg, K. 1975. Analysis of pressuremeter in strain-softening soil. Journal of the Geotechnical Engineering Division 101(GT8): 717-732.

Shao, J.F., Dahou, A. \& Henry, J.P. 1991. Application de la théorie des problèmes inverses à l'estimation des paramètres des modèles rhéologiques. Revue Française de Géotechnique 57: 75-80.

Shahrour, I., Kasdi, A. \& Abriak, N. 1995. Utilisation de l'essai pressiométrique pour la détermination des propriétés mécaniques des sables obéissant au critère de MohrCoulomb avec une règle d'écoulement non associée. Revue Française de Géotechnique 73: 27-33.

Yu, H.S. \& Houlsby, G.T. 1991. Finite cavity expansion in dilatant soils: loading analysis. Geotechnique 41(2): 173183.

Yuritzinn, T. 1981. Comportement des roches après la rupture: Application à la stabilité des ouvrages souterrains par la méthode des éléments finis. PhD. Thesis, Université Paris 6 , Ecole Nationale des Ponts et Chaussées.

Zentar, R., Hicher, P.Y. \& Moulin, G. 2001. Identification of soil parameters by inverse analysis. Computers and Geotechnics 28: 129-144.

French Standard NF P 94-110-1, 1991. Essai pressiométrique Ménard - Partie 1: Essai sans cycle.

Standard ASTM D 4719-87, 1994. Standard test method for pressuremeter testing in soils.

\section{REFERENCES}

Bornarel, B. 1999. Fondations superficielles sur pente et essais pressiométriques - Approche numérique. PhD. Thesis, Ecole Centrale de Lyon. 